\title{
Sergio Guerra
}

Università di Urbino

\section{La conquista dell'ibridità nella fiction di Meera Syal}

doi: 10.7358/ling-2014-001-guer

sergiogue@libero.it

Meera Syal è una delle donne britanniche di discendenza asiatica più note del Regno Unito, "possibly the most influential South Asian woman in the British Media" (Hussain 2005: 15). Il suo talento si è esplicato in varie forme: come drammaturgo all'inizio, come attrice e sceneggiatrice poi, ed infine come romanziere. Il suo play, One of $U$ s, scritto nel 1983, racconta la storia semi-autobiografica di una teenager British Asian che lascia le Midlands dove è cresciuta per diventare un'attrice, e presenta uno dei temi ricorrenti di Syal, la negoziazione di una propria identità a partire da due influenze culturali contrastanti, quella della famiglia di origine e quella del paese in cui uno è nato e cresciuto. Dopo aver recitato nel film seceneggiato da Hanif Kureishi, Sammy and Rosie Get Laid (1987), nel 1992 scrive lo script di Bhaji on the Beach, il primo film diretto da Gurinder Chada. Il film, considerato una pietra miliare del black British cinema, è incentrato su un gruppo di donne British Asian ed Asian, appartenenti a varie generazioni, che effettuano un daytrip da Birmingham a Blackpool. Il viaggio sarà occasione di scontro prima e poi di incontro fra le varie donne, e alla fine della giornata, dalla maggiore conoscenza reciproca nascerà una solidarietà femminile in grado di far fronte anche ad un tentativo di violenza maschile. Anche i temi dell'amicizia tra donne e del loro far fronte comune contro la repressione patriarcale ritorneranno in seguito nella fiction di Syal. Il 1996 è l'anno del suo primo romanzo, Anita and Me, mentre il secondo, Life isn't all ha ha hee hee, è del 1999. Nel frattempo acquisisce massimo successo e visibilità come attrice parte del team, tutto asiatico, che scrive e interpreta la serie comica della BBC, Goodness Gracious Me (1998-2001), una brillante rivisitazione ed inversione di stereotipi riguardanti sia gli asiatici sia gli inglesi. Di grande successo è anche l'altra serie comica in cui appare in seguito, The Kumars at No 42, che viene trasmessa, ancora dalla BBC, dal 2001 al 2006. 
In questo articolo mi propongo di mostrare come nei romanzi di Meera Syal l'ibridità come condizione esistenziale viene intesa come punto di partenza di un percorso di negoziazione tra culture diverse che porta a conquistare una maturità identitaria, che definisco ibridità conclamata, che può essere tale solo nel riconoscimento della necessità di accettare come parte di sé elementi di entrambe quelle culture

\section{ANITA AND ME}

Come sottolinea Sara Upstone, "marketing of both Syal's first novel and its follow up identifies Syal with the 'funny' public image developed through her television work" (Upstone 2010:120). Si enfatizzano gli aspetti più leggeri del libro e vengono promesse molte risate, come è lecito aspettarsi da una comedienne di tale calibro. In questo modo l'opera viene fatta rientrare in quel sottogruppo di fiction commerciale prodotta all'epoca da comici televisivi quali Ben Elton e Stephen Fry, glissando su quegli aspetti del testo che danno ad Anita and $M e$ ben altro spessore ${ }^{1}$. Si può infatti convenire con Mark Stein che quest'opera è un esempio riuscito di black British bildungsroman (cfr. Stein 2004), vale a dire un romanzo di formazione che delinea la traiettoria di un soggetto diasporico da uno stato di innocenza ad uno di relativa maturità.

Meena Kumar, alter ego della stessa Syal, è una bambina di 9 anni che, all'inizio degli anni Settanta, vive con i suoi genitori indiani a Tollington, un piccolo villaggio minerario della Black Country vicino a Wolverhampton. L'adolescenza di Meena, nata in Inghilterra, può definirsi idilliaca, pur essendo lei l'unica bambina 'indiana' del villaggio, ma una serie di avvenimenti ed esperienze le faranno conoscere delusioni, dolori, tradimenti, e la aiuteranno a crescere e a costruirsi un'identità più definita. Meena ha una forte immaginazione e creatività, e ama riorganizzare la realtà, come dimostra la sua ver-

1 Questo non significa in alcun modo sottovalutare il significato e l'importanza dello humour in questo come in altri lavori di Syal. Come sostengono Susanne Reichl e Mark Stein nell'introduzione a Cheeky Fictions: Laughter and the Postcolonial (2005), facendo riferimento tra gli altri proprio a lei, "humour is a key feature, laughter a central element, disrespect a vital textual strategy of postcolonial transcultural practice" (Reichl and Stein (eds.) 2005: 1). Lungi dallo sminuire la serietà della materia trattata fornendo intrattenimento superficiale, il riso in Syal è funzionale al suo progetto di destabilizzazione di discorsi autoritari e stereotipi, un arma imprescindibile per chi, come le protagoniste dei suoi romanzi, si trova a dover smorzare conflitti culturali per negoziare la propria identità. Appoggiandosi sulla suggestione proveniente dalla teoria femminista che la creazione di riso è fonte di potere, Reichl a Stein concludono che "the use of laughter and strategies of unsettling humour contribute to the empowerment of the (post)colonised" (ibidem: 11). La capacità di ridere di entrambe le culture (e di se stesse) testimonia una sicurezza identitaria che è segno di quella ibridità conclamata a cui faccio riferimento sopra.

Linguae \& - 1/2014

http://www.ledonline.it/linguae/ 
sione di un'infanzia diasporica stereotipicamente travagliata e povera che lei snocciola in determinate situazioni "to impress middle class white boys who come sniffing around, excited by the thought of wearing a colonial maiden as a trinket on their arm" (p.10). E aggiunge di seguito:

I've always been a sucker for a good double entendre; the gap between what is said and what is thought, what is stated and what is implied, is a place in which I have always found myself. I'm not really a liar, I just learned very early on that those of us deprived of history sometimes need to turn to mythology to feel complete, to belong (p. 10; corsivo mio) ${ }^{2}$.

Qui c'è già un aspetto centrale dell'opera e, più in generale della situazione dei soggetti diasporici British born/raised: il problema dell'appartenenza. A differenza dei migranti di prima generazione come i suoi genitori, che affondavano le loro radici nella cultura d'origine e avevano vissuto sulla loro pelle l'esperienza traumatica della migrazione, le seconde generazioni di solito sentono quella storia e quelle affiliazioni in maniera tenue, ansiosi di appartenere alla cultura ospitante in cui sono nati. "Meena's narrative (in particular) is distinct from the majority of diasporic writing in that it reveals an affection for the local village community" (Procter 2002), e allo stesso tempo un'impazienza nei confronti dei valori propugnati dalla sua extended family, i genitori e i loro parenti e amici che si riuniscono spesso a casa dei Kumar. Al cibo e ai canti e balli indiani preferisce fish and chips e pop music inglese, alle storie e ai ricordi dei suoi genitori preferisce la lettura di Jackie ${ }^{3}$, e alla compagnia dei suoi cugini preferisce quella dei ragazzi di Tollington. Soprattutto, Meena desidera l'amicizia di Anita Rutter, con la quale darà vita ad una 'gang' femminile, le wenches, e stabilire un contatto più ravvicinato con Sam Lowbridge, lo skinhead locale. Anita, di due anni più grande di Meena, è l'adolescente più appariscente e spregiudicata del villaggio, già esperta nel flirtare con $\mathrm{i}$ ragazzi, che non si fa scrupolo di rubare dolcetti dalla drogheria di $\mathrm{Mr} \mathrm{Or}-$ merod, e non ha paura di scorrazzare nella vasta tenuta della 'Big House', luogo che la leggenda locale vuole abitato da una strega. Per Meena, Anita è un modello da seguire e imitare, così come Sam è un 'oggetto del desiderio', entrambi figure-chiave per affermare la sua appartenenza alla cultura inglese.

Va detto che i genitori di Meena non ostacolano il suo interagire con gli adolescenti locali, a differenza dell'amica di famiglia, Auntie Shaila, che non permette la stessa cosa alle sue due figlie. Vengono così mostrati due atteg-

2 Le citazioni dal testo sono tratte dalla seguente edizione: Meera Syal, Anita and Me (1996), London, Harper Perennial, 2004.

3 Si tratta di una rivista inglese per ragazze molto popolare specialmente negli anni Sessanta e Settanta.

Lingua er - 1/2014

http://www.ledonline.it/linguae/ 
giamenti degli indiani verso la cultura inglese, uno di apertura e uno di chiusura, anche se gli stessi Kumar poi non socializzano tanto con gli abitanti di Tollington (a parte la buona relazione di Mrs Kumar con la signora Worrall e l'amicizia tra $\mathrm{Mr}$ Kumar e il vicario locale, conosciuto come Uncle Alan).

I Kumar sono rappresentati come una coppia ancora molto innamorata, dopo quindici anni di matrimonio, genitori che forniscono una guida e una protezione che Meena all'inizio del romanzo non accetta completamente, ma che apprezzerà sempre di più man mano che la sua maturazione avrà luogo. Il padre, un contabile, e la madre, una maestra, sono più istruiti degli altri abitanti del villaggio, e l'inglese che viene parlato a casa loro lo dimostra. Così Mrs Kumar riprende la figlia che manifesta la sua ribellione giovanile tramite l'uso di gergo e dialetto delle Midlands, ovviamente per essere accettata da Anita e gli altri:

Just because the English can't speak English themselves, does not mean you have to talk like an urchin. You take the best from their culture, not the worst. You'll be swearing and urinating in telephone boxes next, like that Lowbridge boy. (p. 53; corsivo mio)

L'atteggiamento dei coniugi Kumar, che Meena alla fine sottoscriverà, è una sana accettazione delle differenze, e un'idea di integrazione come fusione costruttiva di due culture. Ma all'inizio della storia Meena è ancora ferma su un rifiuto della propria cultura di origine ed una sottoscrizione acritica alla cultura inglese dei suoi coetanei, è divisa al suo interno, con una identità che non riesce ancora a negoziare un'appartenenza non esclusiva. Sarà soprattutto l'esperienza del razzismo a farle mettere in prospettiva i due mondi, e a ridimensionare l'attrazione totale per le cose inglesi. Ci sono vari episodi nel romanzo che dimostrano come il pregiudizio razziale si insinui, a volte in maniera subdola a volte in modo prepotente, nella vita della fino ad allora ignara Meena. A partire del nome del cane dei Rutter, Nigger; racconta Meena:

My mummy nearly choked when I told her what the Rutter's new pet was called. She told papa and he laughed uproariously. 'It is not amusing, Shyam! These no good ignorant English, what kind of a name is that to say in front of your children, anybody's children?' (p. 90)

Più devastante è però un secondo incidente che succede mentre Meena e la madre stanno recandosi in auto a Wolverhampton, e la bambina si trova a doversi rivolgere ad un'anziana signora inglese al volante:

I tapped on the window and the old dear slowly rolled it down. 'Sorry, but me mum's at the top of the hill and she's rolling down, ar ... can yow move back just a bit? Ta.' She blinked once and fumbled with the gear stick and said casu- 
ally, 'Bloody stupid wog. Stupid woggy wog. Stupid.' I backed off as if I had been punched and began running up the hill to our Mini. (p. 97)

Meena è sconvolta, ma quando la sera si accinge a raccontare l'episodio al padre si rende conto che quello che è successo a lei deve essere successo tante volte anche a lui e decide di non dire nulla:

Later that evening, papa pulled me onto his lap and asked what I had learned that day. I wanted to tell him about the old lady, but then I looked at his face and saw something I had never seen before, a million of these encounters written in the lines around his warm, hopeful eyes, lurking in the furrows of his brow, shadowing the soft curves of his mouth. I suddenly realized that what had happened to me must have happened to papa countless times, but not once had he shared his upset with me. He must have known it would have made me feel as I felt right now, hurt, angry, confused, and horribly powerless because this kind of hatred could not be explained. I decided to return the compliment. 'I learned,' I replied, 'that mama is a really good driver.' (p. 98)

Più avanti, nel corso del romanzo, Meena sente i suoi genitori parlare di un gruppo di ragazzi bianchi rasati (skinheads) che ha assalito una sua zia, prendendola a pugni e spaventando i bambini che lei aveva con sé, e anche questo episodio resterà nella sua mente, tanto che se ne ricorderà alla fine nel momento-clou della storia, quando si confronterà con Anita e Sam. Sì, perché proprio Sam Lowbridge, il ragazzo di cui Meena è infatuata, si renderà protagonista di attacchi razzisti, sia verbali sia fisici. Alla festa del paese, interrompe Uncle Alan che sta parlando di spedire una somma di denaro raccolta dalla comunità ad una Missione in Africa, e lo apostrofa così: "You do nothing but talk, 'Uncle'. And give everything away to some darkies we've never met. We don't give a toss for anybody else. This is our patch. Not some wogs' handout.” (p. 193) Meena rimane tramortita da questa violenza verbale:

I felt as if I had been punched in the stomach. My legs felt watery and a hot panic softened my insides to mush. It was as if the whole crowd had turned into a huge eyeball which swiveled slowly between me and papa. (p. 193)

Infine, c'è il gravissimo episodio del pestaggio del direttore di banca, un indiano che era stato poco prima ospite dei Kumar. La famiglia apprende la violenza dal giornale, e questo è per loro fonte di sgomento, ma quando Meena sente Anita vantarsi di avere assistito con piacere al fatto, opera di Sam e dei suoi amici, apre definitivamente gli occhi nei confronti delle persone che aveva fino ad allora considerato amiche:

Anita was high and sharp with excitement and I could hear every word. [...] We went Paki bashing, it was bosting! This Paki was standing at a bus stop, he was in 
a suit, he was dead funny! Nah, I only watched, the lads like did it, you know, and us wenches, we just shouted and held their lager [...] They really did him over and you know what, the stupid bastard didn't do nothing back! (p. 277)

Quando alla fine del romanzo si confronta con Sam, Meena è in grado di tenergli testa e di inchiodarlo alle sue responsabilità:

Those things you said at the Spring fete, what were you trying to do? [...] You wanted to hurt people!' I yelled at him. 'How could you say it, in front of me? My dad? To anyone? How can you believe that shit?

Sam grabbed me by the wrists. 'When I said them,' he rasped, 'I never meant you, Meena! It was all the others, not you!

I put my face right up to his; I could smell the smoke in his breath. 'You mean the others like the bank manager?'

Sam looked confused.

The man from the building site. The Indian man. I know you did it. I am the others, Sam. You did mean me.' (pp. 313-14)

Mentre Meena compie questo percorso di auto-consapevolezza, catalizzato dagli atti razzisti che sperimenta e di cui sente parlare, che la porta a vedere una parte negativa nel mondo che la attrae e a consolidare la sua identità attorno al rifiuto di quella negatività, contemporaneamente si riavvicina alla sua cultura di origine, grazie soprattutto all'arrivo dall'India della nonna, $\mathrm{Na}$ nima ${ }^{4}$. Già in precedenza, nel sentire il padre cantare canzoni indiane, aveva affermato, echeggiando ironicamente il poeta Rupert Brooke, "the songs made me realise that there was a corner of me that would be forever not England" (p.112). Ma quando a Tollington arriva Nanima, Meena è affascinata dalle sue storie e dal suo carisma, e ristabilisce un legame con la sua tradizione culturale imparando persino un po' di dialetto del Punjab. Questa accettazione delle proprie radici le dà forza in un momento difficile, e la aiuta a superara la delusione procuratale da Sam e Anita. La scoperta finale che il ricco proprietario della 'Big House' è un indiano le fa poi intravedere la possibilità di avere successo in Inghilterra pur essendo un soggetto diasporico, ed è con rinnovato entusiasmo che Meena si accinge, facendo contenti i suoi genitori, ad andare alla grammar school e iniziare così un percorso educativo che la porterà via da Tollington. Più sicura della propria identità, Meena proclama alla fine:

I was content $[\ldots]$ The place in which I belonged was wherever I stood and there

4 Questo ruolo dei parenti sulla presa di coscienza delle nuove generazioni si ritrova nel contemporaneo romanzo di Andrea Levy, The Fruit of the Lemon (1999), dove Coral, la zia della protagonista, Faith, è il tramite per la sua acculturazione nella storia della sua famiglia.

Linguae \& - 1/2014

http://www.ledonline.it/linguae/ 
was nothing stopping me simply moving forward and claiming each resting place as home. (p. 303)

Come osserva Dave Gunning,

Anita and Me is detailing Meena’s becoming British Asian [...] able to reach a position where the possibly restrictive elements of cultural hybridity are negotiated into a fruitful and liberated identity. (Gunning 2012: 112)

A differenza di quanto accade nel black British bildungsroman per eccellenza, The Buddha of Suburbia di Hanif Kureishi, dove il protagonista Karim abbraccia soprattutto la cultura inglese, qui Meena 'conquista' la sua ibridità riaffermando il valore della cultura di origine, riconoscendo il suo legame con essa, e superando il rifiuto iniziale.

\section{LIFE ISN'T ALL HA HA HEE HEE}

Anche il secondo romanzo di Syal "moves towards an affirmation of the value of traditional cultures to her protagonists" (Gunning 2012: 113). Ovviamente le differenze tra i due romanzi sono tante, ma come vedremo anche qui la conquista dell'ibridità, intesa come raggiungimento della maturità e della stabilità, comporta per le protagoniste un riavvicinamento alla cultura d'origine. Mantenendo il fuoco sulle figure femminili, Syal crea tre personaggi principali; inoltre sposta l'azione nell'Inghilterra contemporanea (fine anni Novanta), e in un ambiente urbano. Il romanzo narra un anno nella vita di tre donne British Asian, amiche dall'infanzia e ora ultra-trentenni: Chila, Tania e Sunita.

Si inizia con il matrimonio di Chila, la più giovane del gruppo, con Deepak, bello e di successo, l'uomo dei suoi sogni e il migliore partito possibile. Chila è dolce e ingenua, apparentemente meno equipaggiata delle altre ad affrontare le avversità, per questo Tania e Sunita la prendono sotto la loro ala protettiva. Tania è una donna ambiziosa, che ha messo la carriera al di sopra di tutto; è una produttrice televisiva e ha un fidanzato bianco di nome Martin. Sunita infine, la più anziana delle tre, era la 'secchiona' dell'Università, ma l'aveva abbandonata per sposare Akash, diventando moglie e madre premurosa ma con più di un rimpianto. Ad un certo punto le tre amiche si trovano ad affrontare una crisi che mette in pericolo il loro equilibrio e il loro muoversi a proprio agio nella diversità culturale della società inglese, ma dalle difficoltà usciranno rafforzate facendo appello alla solidarietà femminile e trovando conforto nelle loro radici. Il matrimonio di Chila naufraga per i tradimenti di Deepak, quello di Sunita va in crisi per la sua frustrazione ed 
insoddisfazione, mentre Tania è costretta a cedere alle pressioni dei suoi capi e a girare un documentario sulle sue amiche che finisce per metterle in ridicolo, mettendo in pericolo la loro amicizia. In particolare, nella vicenda di Tania, c'è lo scontro fra la sua intenzione di rendere un servizio alla comunità asiatica mettendone in risalto pregi e problemi, e la volontà dei suoi dirigenti bianchi di fare audience puntando sull'esotismo e sul disimpegno:

All those moments where she had sat tight-lipped and buttocks clenched as Rupert or Donald or Angus nibbled on ciabatta and explained to her what it meant to be Asian and British, at least for the purposes of television. [...] 'Well, it's victim mentality TV, isn't it? Let's look at these strange brown people and admire their spunk or pity their struggles. What about the happy stories? What about the Asians who like who they are, who just get on and do it and ... live? Yeah?' (pp. 63-4) ${ }^{5}$

Come ben osserva Gunning, "Syal's apparent demand for the realities of British Asian women's lives to be fairly reflected within representational strategies can be well understood when viewed through the politics of recognition" (Gunning 2012: 115). Il riferimento è al saggio del filosofo canadese Charles Taylor intitolato appunto "The Politics of Recognition" (1992), in cui si mette in evidenza il fatto che la richiesta di 'riconoscimento' (che come concetto va oltre i diritti civili, riguarda la dignità e comporta ottenere rispetto e valorizzazione della propria cultura) emerge nelle odierne società multiculturali da parte dei gruppi minoritari. Scrive Taylor:

The thesis is that our identity is partly shaped by recognition or its absence, often by the misrecognition of others, and so a person or group of people can suffer real damage, real distortion, if the people or society around them mirror back to them a confining or demeaning or contemptible picture of themselves. Nonrecognition or misrecognition can inflict harm, can be a form of oppression, imprisoning someone in a false, distorted, and reduced mode of being. (Taylor 1992: 25)

Nel caso dei capi di Tania, quello che viene negato è il riconoscimento della realtà complessa della comunità asiatica, del valore della cultura indiana, una cultura di pari dignità di quella inglese e non semplice curiosità da proporre come intrattenimento.

Questo bisogno di 'riconoscimento' culturale è anche ciò che mette in crisi il suo rapporto con Martin, che nonostante la buona volontà non è in grado di darle, nel momento di crisi, una comprensione da insider del suo disagio, quell'abbraccio della sua comunità etnica di cui lei ha bisogno:

5 Le citazioni dal testo sono tratte dalla seguente edizione: Meera Syal, Life isn't all ha ha hee hee (1999), London: Black Swan, 2000. 
Tania shook her head, not knowing why she felt tearful. [...]

'Hey', Martin said again, 'What's up?'

Tania did not know how to tell him. What was up was that she wished he would call her jaan. (p. 72)

L'ambientazione del romanzo nell'East End londinese marca una differenza importante, come dicevamo, rispetto ad Anita and Me. Mentre la campagna inglese ha sempre visto una scarsissima presenza di asiatici, l'area di Spitalfields e Brick Lane può essere considerata come il centro simbolico della comunità asiatica in Gran Bretagna. Per cui, nel tracciare traiettorie esistenziali individuali, Life isn't all ha ha hee hee mette in campo l'idea di una comunità che, se all'inizio ha un importanza marginale per le tre amiche, alla fine eserciterà un'attrazione e un'influenza positive sulle loro vite. Suzanne Reichl parla di un'identità asiatica da cui le donne sono alienate all'inizio ma a cui si avvicinano man mano che la storia progredisce (Cfr. Reichl 2002).

Va detto che comunque l'apprezzamento del valore della tradizione culturale dei propri genitori non è mai disgiunta da una critica decisa a certi aspetti di essa, in particolare il maschilismo, la componente patriarcale. Questa critica è chiara nell'episodio che riguarda un personaggio secondario, Jasbinder Singh. Jasbinder divorzia da suo marito e lui reagisce rapendo i suoi figli e poi uccidendoli e suicidandosi, incapace di accettare che la moglie possa godere dei diritti individuali garantiti dalla liberale Gran Bretagna. Anche Deepak ad un certo punto rapisce il bambino che ha avuto da Chila, ma è impossibilitato a lasciare il paese perché Tania ruba e distrugge il suo passaporto. Alla fine il bambino viene riconsegnato alla madre, e le amiche si ritrovano e si riconciliano tra loro. Anche quest' episodio dimostra che ci sono aspetti della tradizione etnica in questione, il sessismo in particolare, che contrastano con le idee liberali inglesi, e che quando i diritti individuali non vengono rispettati è lecito criticare e cercare di cambiare quelle idee tradizionali. Ma, va ribadito, l'aspetto più interessante del romanzo è che queste tre donne emancipate occidentali sentano alla fine il bisogno di ripiegare sulla tradizione indiana per costruire un identità ibrida solida e stabile, in grado di fronteggiare le sfide poste dal complesso mondo contemporaneo. È proprio Chila, la meno consapevole in apparenza, che scopre per prima l'importanza di questo ripiegamento:

Some of the old rules hold you up; trouble is, you only find that out when they're being carted off in the rubbish van and you're left on the pavement in an embarassing nightie wondering who's going to tell you what's right now. (p. 33)

Le fa eco più avanti Tania:

We three girls managed the oft-quoted juggling act until it was time to find a man. See how I combine this bindi with that leather jacket and make a bold statement 
about my duality? Look! I can go to a rave one night, and the next morning be cooking in the communal temple kitchen! Watch how I glide effortlessly from old paths to new pastures, creating a new culture as I walk on virgin snow! And then it was time to cut all the crap and own up to who we really are. (p. 148)

Il romanzo termina con Sunita che ricostruisce il suo matrimonio, Chila che è diretta in India con suo figlio, e Tania che si dedica a progetti televisivi che cercano di aiutare gli asiatici in Gran Bretagna, invece di usarli come prodotti di consumo esotici, tutte e tre impegnate e consce dell'importanza del proprio background culturale.

\section{Conclusione}

Com'è noto, il concetto di ibridità, che possiamo definire come la conseguenza del contatto tra due o più culture sull'identità dei soggetti, ha avuto molta fortuna nella teoria postcoloniale, dalle riflessioni di Salman Rushdie alle formulazioni di Homi Bhabha, Stuart Hall e Paul Gilroy. Pur diversificandosi nella maniera di declinare il concetto, questi critici hanno in comune una visione positiva dell'ibridità stessa, che contrasta con la sua demonizzazione razzista nell'ambito della vecchia ideologia imperiale. Allora (purtroppo per alcuni ancora) mescolanza significava contagio, corruzione, impurità; oggi la si celebra da più parti come potenzialità, fusione costruttiva, novità rigeneratrice. Scrive Rushdie facendo riferimento ad un suo famoso romanzo:

The Satanic Verses celebrates hybridity, impurity, intermingling, the transformation that comes of new and unexpected combinations of human beings, cultures, ideas, politics, movies, songs. It rejoices in mongrelization and fears the absolutism of the Pure. Mélange, hotchpotch, a bit of this and a bit of that is how newness enters the world. It is the great possibility that mass migration gives the world, and I have tried to embrace it. (Rushdie 1991: 394)

Dobbiamo sempre ricordarci però di pensare anche le identità ibride come costruzioni fluide, in progress, che si conformano all'idea di identità proposta da Stuart Hall:

Perhaps instead of thinking of identity as an already accomplished fact $[\ldots]$ we should think of identity as a 'production', which is never complete, always in process. (Hall 1990: 222)

Questo a mio parere non deve sottintendere un'evoluzione continua ed infinita, ma un succedersi di momenti di assestamento catalizzati da eventi for- 
mativi significativi, traumatici o meno. Quando nell'articolo parlo di 'conquista' dell'ibridità intendo non il 'raggiungimento' della stessa, che è già data in partenza, costitutiva dell'identità di soggetti a cavallo tra due culture, ma il risultato della negoziazione tra esse, un 'padroneggiare' l'ibridità nel senso di una gestione sicura delle risorse a disposizione che si traduce in un'identità relativamente solida e stabile, che può permettersi, come dicevamo all'inizio (cfr. nota 1), anche di ridere di entrambe quelle culture. È quello che ottengono sia Meena, sia Chila, Sunita e Tania, che possono essere considerate (i tempi collimano) versioni adulte della stessa Meena, possibili approdi del suo percorso esistenziale. La crisi che tutte a loro modo sperimentano le spinge a fare appello a tutte le loro risorse, e dalla successiva negoziazione scaturisce quell'appoggiarsi alla cultura fino ad allora messa in secondo piano, quella tradizionale indiana, ristabilendo un equilibrio interno estremamente fecondo.

Ovviamente, quello dei personaggi di Syal non è l'unico approdo possibile per soggetti diasporici in-between. Possiamo dire per esempio che personaggi di Hanif Kureishi come Karim di The Buddha of Suburbia o Shahid di The Black Album non 'conquistano' l'ibridità ma la 'subiscono' soltanto, puntando tutto sulla cultura inglese e facendo così appello ad una sola delle risorse disponibili. A conferma della sua personale posizione, Kureishi ha rivelato: "critics have written that I'm caught between two cultures. I'm not ... I've made it in England" (cit. in Kaleta 1998: 7). La negoziazione tra le due (o più) culture che formano il soggetto ibrido può avere dunque risultati vari, ma certamente si può affermare che l'ibridità conclamata, cioè lo sfruttamento pieno delle risorse, comporta una valorizzazione di entrambe quelle culture; le protagoniste dei due romanzi di Meera Syal presi in esame sono incarnazioni romanzesche riuscite e convincenti di questa posizione culturale.

\section{BIBLIOGRAFIA}

Gunning, D. (2012), Race and Antiracism in Black British and British Asian Literature, Liverpool, Liverpool University Press.

Hall, S. (1990), "Cultural identity and diaspora", in J. Rutherford (ed. 1990), Identity: community, culture, difference, London, Lawrence and Wishart.

Hussain, Y. (2005), Writing Diaspora: South Asian Women, Culture and Ethnicity, Aldershot, Ashgate.

Kaleta, K. (1998), Hanif Kureishi: Postcolonial Storyteller, Austin, University of Texas Press. 
Procter, J. (2002), Meera Syal, http://literature.britishcouncil.org/meera-syal

Reichl, S. (2002), Cultures in the Contact Zone: Ethnic Semiosis in Black British Literature, Wissenschaftlicher Verlag Trier.

Reichl, S. and Stein, M. (eds. 2005), Cheeky Fictions: Laughter and the Postcolonial, Amsterdam, Rodopi.

Rushdie, S. (1991), Imaginary Homelands, London, Vintage, 2010.

Stein, M. (2004), Black British Literature. Novels of Transformation, Columbus, The Ohio State University Press.

Syal, M. (1996), Anita and Me, London, Harper Perennial, 2004.

Syal, M. (1999), Life isn't all ha ha hee hee, London, Black Swan, 2000.

Taylor, C. (1992), "The Politics of Recognition", http://elplandehiram.org/ documentos/JoustingNYC/Politics_of_Recognition.pdf; trad. it. "La politica del riconoscimento", in J. Habermas e C. Taylor, Multiculturalismo. Lotte per il riconoscimento, Milano, Feltrinelli, 1998.

Upstone, S. (2010), British Asian Fiction. Twenty-first-century voices, Manchester, Manchester Press.

\section{ABSTRACT}

The aim of this essay is to explore Meera Syal's novels - Anita and Me and Life isn't all ha ha hee hee - and to suggest that they show and sponsor a level of hybridity that I call 'ibridità conclamata' (full-blown hybridity), a condition in which the diasporic subject makes the most of the cultures that constitute him/her. At the end of both novels the female protagonists, who overcome their various crises and reach a more mature and balanced identity by valuing elements of the culture they had rejected - in this case traditional Indian culture - represent fictional embodiments of that kind of hybridity. What is implied here, and what the article tries to make clear, is that hybridity, to bring to fruition its positive potential, should not be thought of as a fixed condition but as involving continuous negotiation aimed at using to the full all the cultural resources available. 